\title{
THE CONSUMER PERCEPTION ON QUALITY OF THE PEARL JEWELRY CRAFTS PRODUCTS MATARAM
}

\author{
Muhamad Ilhamudin, Santi Nururly, Rusminah, Hilmiati \\ 1 Faculty of Economics and Business, Mataram University \\ Email : Ilham.alfian226@gmail.com \\ 2,3,4 Faculty of Economics and Business, Mataram University
}

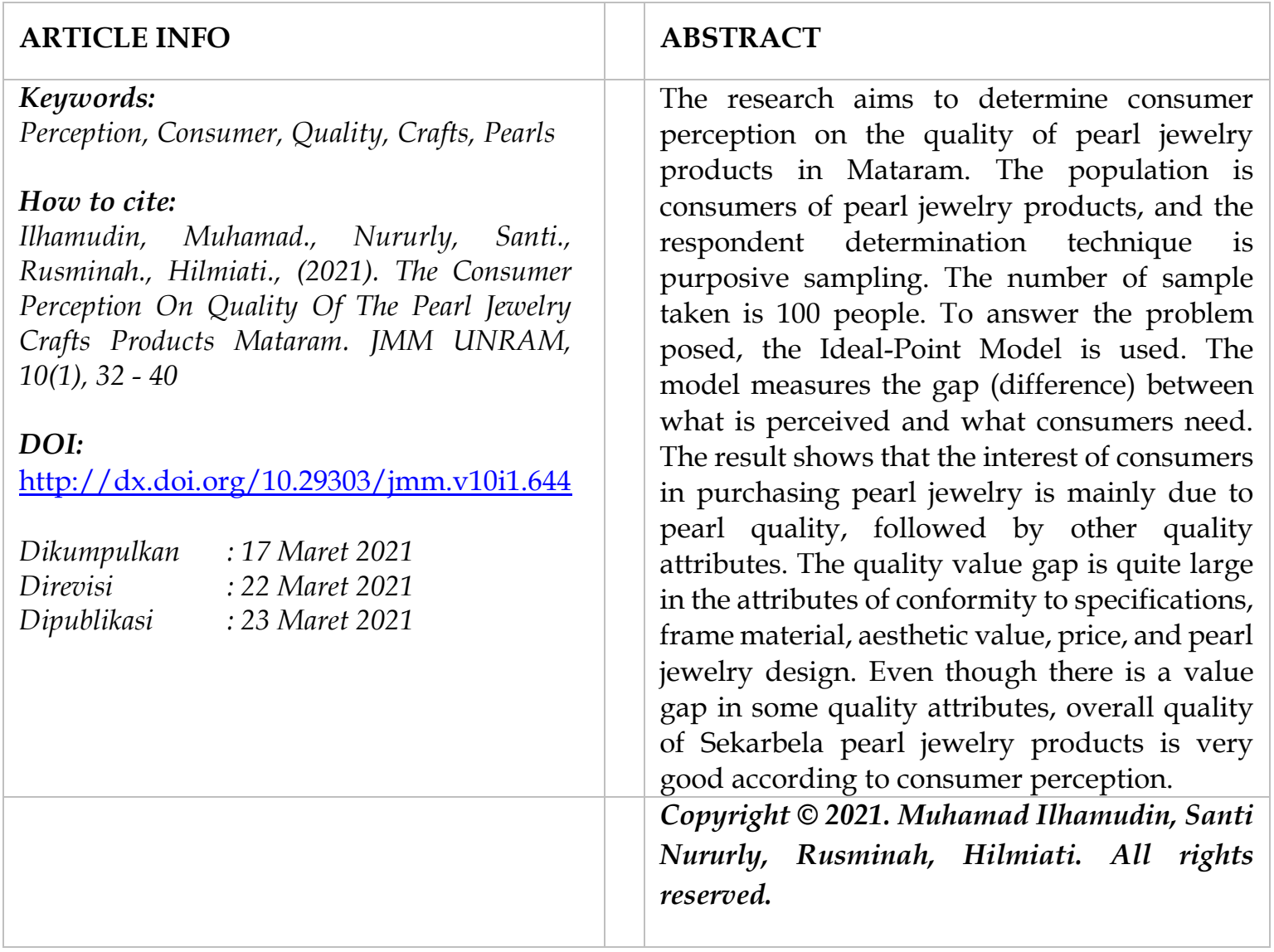

\section{INTRODUCTION}

The Ministry of Trade Republic Indonesia noted the contribution of the creative industry to Indonesia's GDP in 2002 to 2006 was an average of $6.3 \%$ or equivalent to 152.5 trillion if converted to rupiah. The creative industry as one of new and potential fields in the Indonesian industrial field which is able to absorb up to 5.4 million workers with a participation rate of $5.8 \%$. In terms of exports, the creative industry posted total exports of $10.6 \%$ between 2002 and 2006. 
A reason for developing the potential of creative industry is its positive impact on people's lives, the business climate, economic improvement, and also an impact on the image of area. The existence of creative industry directly or indirectly can be attraction and can encourage people to come or visit a place.

Mataram city has a potential creative industry which, if managed properly, will be a driving force for tourism destinations in that place. One of the creative industries that have good prospects is pearl jewelry craft which is located at Sekarbela craft center, a part city of Mataram. The handicraft plays its own role because it already has international market potential, and also includes local wisdom in using production factors.

Research on product quality plays a very important role in helping companies know what to produce and improve. Research conducted by Raras (2014) states that product quality is the ability of product to carry out its functions which include durability, reliability, ease of packaging and product improvement and other characteristics. Ilhamudin (2018) states the sustainability of pearl jewelry creative industry in Mataram is determined by product development. The progress of the pearl jewelry industry cannot be separated from the creativity of the producers in creating design and product quality. Based on these conditions, research on consumer perceptions of quality is important to be carried out for sustaining the business, therefore it can be able to increase the welfare of business players and at the same time moving up the economy of the region.

\section{THEORETICAL REVIEW}

\subsection{Product Quality}

According to Kotler and Armstrong (2008: 22) quality is a characteristic of a product in its ability to meet predetermined and latent needs. Meanwhile, according to Alma (2011: 76) quality is the advantage that the product has. Quality in the view of consumers is something that has its own scope that is different from the quality in the view of the producer when issuing a product that is commonly known for its true quality.

According to Kotler and Armstrong (2008:32) the meaning of product quality is "the ability of a product to perform its functions, it includes the product's overall durability, reliability, precision, ease of operation and repair, and other valued attributes" which means ability. a product in demonstrating its function, it includes overall durability, reliability, accuracy, ease of operation and product repair as well as other product attributes. According to Kotler (2009: 56), quality is defined as the overall characteristics and characteristics of goods and services that affect the ability to meet stated and implied needs. Meanwhile, according to Tjiptono Fandy (2008: 66), quality is a combination of traits and characteristics that determine the extent to which output can meet customer requirements or assess to what extent those characteristics and characteristics meet their needs.

Based on the definitions above, it can be concluded that quality is a product and service that goes through several stages of the process by taking into account the value of a product and service without the slightest deficiency in the value of a product and service, and produces products and services according to the high expectations of customers.

To achieve the desired product quality, a quality standardization is needed. This method is intended to ensure that the products produced meet the predetermined standards so that consumers will not lose confidence in the product concerned. Marketers who do not pay attention to the quality of the products offered will bear the disloyalty of consumers so that sales of their products will tend to decline. If marketers pay attention to quality, even reinforced by advertising and reasonable prices, consumers will not think long about making purchases of products (Kotler and Armstrong, 2008: 55). Based on the explanation above, it

jmm.unram.ac.id 
can be concluded that the quality of the product is all goods and services related to the desires of consumers, which are superior to the product being sold according to the expectations of the customer. 


\subsection{Reasons For Producing Quality Products}

A product that has prime quality will indeed be more desired by consumers, and in the end it can increase sales volume. But more than that, quality products have another important aspect, namely (Prawirosentono, 2002: 2). Consumers who buy products based on quality generally have greater product loyalty compared to consumers who buy based on price orientation. Quality-based consumers will always buy the product until the product makes them feel dissatisfied because there are other higher quality products. But as long as the original product always makes quality improvements, it will remain loyal by continuing to buy it. In contrast to price-based consumers, they will look for products that are cheaper, regardless of brand. So the last consumer has no product loyalty.

Contradictory to the traditional business mindset, it turns out that producing quality goods is not automatically more expensive by producing low quality products. Many companies find that producing quality products does not have to cost more. Producing high quality products simultaneously increases productivity, including reducing material use (reduce material susage) and reducing costs.

Selling bad quality goods, is likely to receive a lot of complaints and returns from consumers. Or the cost to fix it will be very large, apart from getting a bad image. Not to mention, accidents suffered by consumers due to the use of low quality products. The consumer may sue for compensation in court. Based on these three reasons, producing high quality products will provide more benefits for producers, when compared to producers who produce low quality products.

Quality is a factor contained in a product that causes a product to be valued according to the purpose for which the product was produced. Quality is determined by a set of uses or functions, including durability, dependence on other products or components, exclusivity, comfort, external appearance (color, shape, packaging, etc.). The issue of product quality is a central issue for every company. The company's ability to provide quality products will be a weapon to win the competition, because by providing quality products, consumers will feel satisfied with the products they have consumed or in other words, consumer satisfaction will be achieved.

\subsection{Product Quality Dimensions}

According to Tjiptono Fandy (2008: 33), quality reflects all dimensions of product offerings that generate benefits for customers. The quality of a product either in the form of goods or services is determined by its dimensions. The dimensions of product quality according to Tjiptono Fandy (2008: 36) are:

1. Performance (performance), related to the basic operating characteristics of a product.

2. Durability (durability), which means how long or how long the product in question lasts before the product has to be replaced. The greater the frequency of consumer use of the product, the greater the power of the product.

3. Conformance to specifications, namely the extent to which the basic operating characteristics of a product meet certain specifications from consumers or are not found defects in the product.

4. Features, are product characteristics designed to enhance product functions or increase consumer interest in the product.

5. Aesthetics (aesthetics), relates to how the product looks.

6. Perceived quality is often said to be the result of using measurements that are carried out indirectly because there is a possibility that consumers do not understand or lack information on the product in question. 
7. Serviceability, including speed and ease of repair, as well as the competence and friendliness of service staff.

Based on the dimensions above, it can be concluded that a quality dimension is a requirement so that a value of the product allows it to satisfy customers as expected, while the dimensions of product quality include performance, durability, conformance to specifications (conformance to specifications). specifications), features (features), aesthetics (aesthetics), perceived quality (impression quality), and serviceability.

\section{RESEARCH METHOD}

\subsection{Types of Research}

The research is a descriptive due to its method focuses on solving problems that exist in the busisness at present time. Furthermore, the data collected is compiled, explained and then analyzed (Surakhmad, 1998: 140). In this case, descriptive research is used to obtain an overview of the quality of the creative industry products, namely pearl jewelry craft which is one of the superior products of the city of Mataram, which is located in the Sekarbela craft center.

\subsection{Determination of Respondents}

The population in this research were all consumers of jewelry products who had purchased Sekarbela pearl jewelry. The technique of determining the respondents was purposive sampling, namely sampling according to the research objectives. If it is considered that the person who happened to be met is suitable as the data source based on the criteria in selecting respondents as follows:

1. Consumers who have made a purchase.

2. Adults, where adults are categorized as 17 years of age or older or married, the researcher assumes that respondents who are 17 years old understand the questions asked. Respondents are decision makers in purchasing tofu.

3. The assumption in the relation to the respondent is that in making decisions consumers evaluate the attributes contained in the products.

Because the number of population is not known with certainty, the sample taken for the study was 100 people. This number has met the minimum sample size, which is between 30 and 500 as stated by Roscoe in Wibisono (2003: 55). The determination of the sample size is also in accordance with the opinion of Guilford (1987: 125) which states that the research sample includes a number of elements (respondents) that are greater than the minimum requirements of 30 elements or respondents.

\subsection{Data Analysis Procedure}

According to Sumarwan (2003: 164), to determine consumer perceptions of pearl jewelry, the Ideal-Point Model is used. In principle, the ideal number model provides information about consumer evaluations of what consumers perceived and what consumers want (ideal). This model measures the gap (difference) between the ideal and what consumers actually feel. The analytical procedure used in the study is as follows:

1. In order to find out consumer perceptions of what consumers actually perceived on pearl jewelry products, consumers are asked to provide an assessment of the attributes as they are actually felt which are assessed on a scale of 1 to 5 .

2. To find out the ideal characteristics desired by consumers using the Ideal Quality Analysis of Consumers. Each consumer has the ideal nature of the product 
according to their respective desires. The ideal of the product by looking at the point difference between ideal performance and trust in the attributes of pearl jewelry.

3. To find out consumer perceptions of pearl jewelry products by using the Ideal-Point Model. The consumer perception criteria are assessed using a linear numerical scale with the formula:

$\mathrm{x}=\frac{\sum \mathrm{Wi}(\mathrm{Ii}-1)}{\text { Scale }}$

Numeric Linear Scale:

$0 \leq \mathrm{Ab}<\mathrm{x}$ Very good

$\mathrm{x} \leq \mathrm{Ab}<2 \mathrm{x}$ Good

$2 \mathrm{x} \leq \mathrm{Ab}<3 \mathrm{x}$ Neutral

$3 \mathrm{x} \leq \mathrm{Ab}<4 \mathrm{x}$ Bad

$4 \mathrm{x} \leq \mathrm{Ab}<5 \mathrm{x}$ Very Bad

\section{RESULTS AND DISCUSSION}

\subsection{Analysis of Consumer Interests in Buying Pearl Jewelry Products}

Consumer interest is a consumer statement regarding the order of importance of an attribute attached to pearl jewelry. The consumer's decision to buy a product will previously consider these attributes according to their importance. The attributes attached to jewelry products will attract consumers to make purchases.

In this study, there are six (6) attributes measured, namely product durability, aesthetic value, pearl quality, suitability of specifications, features, and jewelry design. Data collection using a questionnaire instrument using google form, was carried out in June - July 2020. The following describes the interests of pearl jewelry consumers in general when purchasing these products.

Table 4.1. The Consumer Interests in Pearl Jewelry Attributes

\begin{tabular}{|c|l|c|c|c|c|c|c|c|c|c|}
\hline No & \multicolumn{1}{|c|}{ Attributes } & $\begin{array}{c}\text { ST } \\
(\mathbf{1})\end{array}$ & $\begin{array}{c}\text { TP } \\
\mathbf{( 2 )}\end{array}$ & $\begin{array}{c}\mathbf{C} \\
\mathbf{( 3 )}\end{array}$ & $\begin{array}{c}\text { PT } \\
\mathbf{( 4 )}\end{array}$ & $\begin{array}{c}\text { SPT } \\
\mathbf{( 5 )}\end{array}$ & Total & $\mathbf{N}$ & $\mathbf{W}_{\mathbf{i}}$ & Rank \\
\hline 1 & Product durability & 0 & 0 & 16 & 22 & 62 & 446 & 100 & 4,46 & 6 \\
\hline 2 & Aesthetic value & 0 & 0 & 14 & 19 & 67 & 453 & 100 & 4,53 & 5 \\
\hline 3 & Pearl quality & 0 & 0 & 3 & 10 & 87 & 484 & 100 & 4,84 & 1 \\
\hline 4 & Conformity to specifications & 0 & 0 & 12 & 18 & 70 & 458 & 100 & 4,58 & 4 \\
\hline 5 & Frame material & 0 & 0 & 9 & 15 & 76 & 467 & 100 & 4,67 & 3 \\
\hline 6 & Design & 0 & 0 & 7 & 12 & 81 & 474 & 100 & 4,74 & 2 \\
\hline 7 & Price & 0 & 0 & 17 & 23 & 60 & 443 & 100 & 4,43 & 7 \\
\hline
\end{tabular}

Data source: primary data processed

The research result shows that the respondents state that pearl quality is the most important attribute when consumers decide to purchase pearl jewelry. Then followed by design attributes, frame material, conformity to specifications, aesthetic value, durability, and finally price attributes.

Pearl quality is determined by several variables, namely pearl shape, luster, surface, color, and pearl size. Pearl shapes consist of 3 categories, namely spherical, symmetrical, and baroque. The rarest and most valuable form is the spherical shape (perfectly round pearl), the rarer and more perfectly round the pearl the more expensive the original pearl is. Pearls with a teardrop-like or pear-like shape are called symmetrical pearls, and are judged by their proportions, outline, and balance (symmetry). The more balanced the shape, the better and more expensive the pearl price will be. A pearl that is not round (irregular) but still attractive 
is the baroque shape. The round shape is the shape with the most expensive pearl price, then the symmetrical shape, the last real pearl which is the cheapest is the baroque pearl.

Jewelry design is the second most important attribute. Consumers want innovative designs because tastes and needs develop, they want designs that follow current trends, some want designs that are glamorous. However, consumers also want jewelry designs that can build a more chick and edgy appearance, but still look luxurious. Consumers also want to be able to design their own jewelry.

Frame material is the next important attribute. The frame material consists of 22 carat gold, with $91 \%$ pure gold content. Silver with a grade of $92.5 \%$ does not fade quickly, does not change color, if it changes color due to poor maintenance. Rhodium, a mixture of several metals such as silver copper coated with white gold. The advantages of rhodium are the glossy color of the frame, it does not change color easily, if it changes color it often tarnishes with water and for a very long time. Prices are relatively cheap compared to gold and silver frames because they are not calculated per gram but per pcs. Then, stainless steel is used in binding jewelry, the metallic color is shiny. The price is cheaper than gold, silver, rhodium, affordable and cheap.

The next important attribute is specification conformity. The product packaging contains specifications of pearl quality, frame material, total weight, and other information related to the product. For example, pearl necklace jewelry specifications are $18 \mathrm{~K}$ gold metal, real black pearl from the Tahiti sea, the total weight of the jewelry is 1.7 grams, the best technology in processing (3D), the IGS (International Gemological Service) jewelry certification, a jewelry box, and a card. warranty. Consumers will build their trust in the seller when the specifications match the reality of the product. Thus consumers state this attribute is something important.

For consumers, aesthetic value is an important attribute. Consumers state the aesthetic value of pearl jewelry products is when the jewelry can exude beauty that presents an elegant impression, is beautiful to look at when worn, comfortable to wear, not too big or heavy, with the best quality and affordable prices, it can provide a new experience for the wearer.

Durability is an important attribute after aesthetic value. However, the durability of pearl jewelry products depends a lot on the material frame and the way of care. Rhodium frame material is the most expensive of all the metals used in jewelry, it is a very hard metal and does not fade. How to care also affects product durability, so it is necessary to understand how to better care for jewelry so that jewelry lasts long.

Price is the last attribute that pearl jewelry consumers consider. However, price is related to other quality attributes such as pearl quality, frame material, design and so on. In general, the higher the quality of the product the higher the price.

\subsection{Gap Value Analysis on the Quality of Sekarbela Pearl Jewelry Products}

Analysis of the value gap on quality is used to measure the extent to which the performance of a product has met the ideal characteristics desired by consumers. Through this analysis, it can be seen whether the attributes attached to the quality of the product have or are not in accordance with consumer desires. The value of the gap in quality is obtained by comparing the actual value of the attribute performance with the ideal value as can be seen in the following table. 
Table 4.2. The Gap Value in the Quality of Sekarbela Pearl Jewelry Products

\begin{tabular}{|c|l|c|c|c|}
\hline No & \multicolumn{1}{|c|}{ Attributes } & Ideal & Actual & Value Gap \\
\hline 1 & Product durability & 4,30 & 4,00 & 0,30 \\
\hline 2 & Aesthetic value & 4,24 & 3,64 & 0,60 \\
\hline 3 & Pearl quality & 4,28 & 4,16 & 0,12 \\
\hline 4 & Conformity to specifications & 4,46 & 3,74 & 0,72 \\
\hline 5 & Frame material & 4,40 & 3,80 & 0,60 \\
\hline 6 & Design & 4,28 & 3,70 & 0,58 \\
\hline 7 & Price & 4,45 & 3,80 & 0,65 \\
\hline
\end{tabular}

Source: primary data processed

The table above shows the ideal quality of Sekarbela pearl jewelry products by looking at the attributes inherent in the quality context. If the quality attributes are sorted based on the least gap value, the first is pearl quality, followed by durability, design, aesthetic value, frame material, price, and finally conformity to specifications. Two attributes, namely pearl quality and product durability, have a gap of less than 0.50 which means that they have almost fulfilled consumer desires, while the other five attributes have a gap greater than 0.50 or have not fulfilled consumer desires.

The pearl quality attribute best fulfills consumer desires due to the fact that the quality of Lombok pearls is well known even to foreign countries with the smallest difference in value, namely 0.12 . This means that the quality of pearls is in accordance with their wishes, even the attributes are a top priority for consumers to consider buying pearl jewelry.

The second attribute that fulfills ideal characteristics or fulfills consumer desires is product durability with a value difference of 0.30 . The durability of the jewelry product depends on the care method and the material for the pearl bead frame. Consumer participation in the care of products that have been purchased also forms the small value of the gap in the product durability attributes.

Finally, the suitability of specifications is the fourth most important attribute for consumers when deciding to buy pearl jewelry. Correct information regarding the product is needed by consumers when there is the biggest gap of all existing attributes, namely 0.72 . Honest and true information about the product and its specifications can be done through online media or on the product packaging.

\subsection{Consumer Perceptions of the Quality of Sekarbela Pearl Jewelry Products}

Marketers must know the wants and needs of consumers which are reflected in their assessment of products that are bought again or to be purchased. The perception in this study is more to see the response of consumers whether they like or dislike certain products because of their quality indicators.

Perception of Sekarbela pearl quality is based on the measurement of a number of quality attributes, the closer a product quality is to the ideal quality, the better its position is in the minds of consumers, and vice versa. The quality attributes referred to are product durability, aesthetic value, pearl quality, conformity to specifications, frame material, design and price. These consumer perceptions can be seen in the table below. 
Table 4.3. Consumer Perceptions on the Quality of Sekarbela Pearl Jewelry Products

\begin{tabular}{|c|l|c|c|c|}
\hline No & \multicolumn{1}{|c|}{ Attributes } & $\begin{array}{c}\text { Importance } \\
\text { Value }\end{array}$ & Quality Gap & Quality Value \\
\hline 1. & Product durability & 4,46 & 0,30 & 1,338 \\
\hline 2. & Aesthetic value & 4,53 & 0,60 & 2,718 \\
\hline 3. & Pearl quality & 4,84 & 0,12 & 0,5808 \\
\hline 4. & Conformity to specifications & 4,58 & 0,72 & 3,2976 \\
\hline 5. & Frame material & 4,67 & 0,60 & 2,802 \\
\hline 6. & Design & 4,74 & 0,58 & 2,7492 \\
\hline 7. & Price & 4,43 & 0,65 & 2,8795 \\
\hline \multicolumn{4}{|c|}{ Total } \\
\hline
\end{tabular}

Source: primary data processed

The table above shows the importance value of each quality attribute multiplied by the gap value, as the basis for determining the position of the product quality figure according to consumer perceptions. The total number of quality attribute numbers is 16,3651 which is formed from the smallest attribute quality figures for pearl quality, followed by product durability attributes, specification suitability, design, aesthetic value, frame material, and finally product price attributes. The smaller the product attribute quality figures, the better the consumer's perception of these attributes, and vice versa. Thus the pearl quality attribute has the best quality because the quality score is the least 0.5808 , while the suitability of specifications is the attribute that has the highest quality score among all attributes, namely 3.2976.

The quality score of 16,3651 is at the top interval, namely $0<16.04<21.60$. This means that consumers assess the quality of Sekarbela pearl jewelry products as very good as a whole, even though partially some of the attributes have not fulfilled consumer desires because they have a large enough gap.

\section{CONCLUSIONS AND MANAGERIAL IMPLICATIONS}

\subsection{Conclusion}

Based on the results of research on consumer perceptions of the quality of pearl jewelry products in the city of Mataram, the following conclusions can be drawn:

1. In terms of analysis of the interests of consumers in purchasing pearl jewelry products, it is found that pearl quality is the most important attribute why consumers buy, followed by design attributes, frame materials, conformity to specifications, aesthetic value, durability, and finally price attributes.

2. The value of the gap in the quality of Sekarbela pearl jewelry products is the biggest in the specification suitability attribute, which means that the quality attribute has not fulfilled consumer desires followed by the price attribute, frame material, aesthetic value, and design. Two other attributes, namely pearl quality and durability, have fulfilled the ideal characteristics of consumers.

3. The value of product quality according to consumer perceptions is at very good intervals. This means that the overall quality of Sekarbela pearl jewelry products is very good, although partially some of the attributes have not fulfilled the desires of consumers because they have a large enough gap

\subsection{Managerial Implications}

Starting from the findings in the research, suggestions are put forward to producers and marketers of the Sekarbela pearl jewelry industry as follows: 
1. Producers or marketers in this industry should pay particular attention to design, frame materials, and conformity to specifications. This industry is a fashion industry category whose changes follow global trends so that jewelry designs must respond to these changes. Likewise, the quality of the frame material will bind the jewelry better, the better the frame material, the stronger the durability of the jewelry product. Consumers trust will be formed when producers or marketers provide correct information about product specifications, especially regarding the type of pearl, weight and size, frame material either through online information or information attached to the package.

2. Consumers already know the quality of Lombok pearls, so producers should build relationships with suppliers who provide high quality pearl granules. The wellknown quality of Lombok pearls can be used as a core content by the Sekarbela jewelry industry in continuous marketing communications to seize national and even foreign markets.

\section{REFERENCES}

Alma, Buchari. 2011. Manajemen Pemasaran dan Pemasaran Jasa. Bandung: Penerbit Alfabeta. Guilford, J.P and Fruchter B. 1987.Fundamental Statistik In Psychology and. Education, Fifth Edition. McGraw-Hill. Kogakusha, Ltd.

Ilhamudin, Santi, Rusminah. 2018. Analisis Strategi Pengembangan Industri Kreatif Perhiasan Mutiara Kota Mataram. JMM Unram.

Kanuk, Schiffman. 2007. Perilaku Konsumen. Edisi Ke-7.Diterjemahkan oleh Zoelkifli Kasip. Jakarta: PT. Indeks.

Kotler, Philip. 2009.Marketing Management. New Jersey: Prentice Hall.

Kotler, Phillip dan Kevin L. Keller. 2016. Marketing Management. 16 ${ }^{\text {th }}$ Edition. New Jersey: Pearson.

Raras, Wiyati. 2014. Analisis Pengaruh Kualitas Produk, Promosi, dan Kualitas Layanan Terhadap Keputusan Pembelian (Studi pada Toko Emas Karunia di Cepu Jawa Tengah). Skripsi.

Sumarwan, Ujang. 2011. Perilaku Konsumen: Teori dan Penerapannya dalam Pemasaran. Jakarta: Ghalia Indonesia.

Surakhmad.1998. Metode Penelitian Sosial. Bandung.PT. Remadja Rosdakarya. Tjiptono, Fandy. 2008. Manajemen Jasa. Yogyakarta: Andi Offset.

Wibisono, Dermawan. 2003. Riset Bisnis. Jakarta. PT. Gramedia Pustaka Utama. www.bps.go.id 